\title{
EVALUATING THE RELATION BETWEEN ORGANIZATIONAL LEARNING CULTURE AND CUSTOMER SATISFACTION USING JOB SATISFACTION'S MEDIATING VARIABLE IN INSURANCE INDUSTRY
}

\author{
Alireza Maleki \\ Islamic Azad University Central Tehran Branch, Faculty of Management \\ maleki.ar87@yahoo.com
}

\begin{abstract}
The number of carried out activities in the academic field with the subject of organizational learning culture, customer satisfaction and job satisfaction has not been limited in Iran but in the meantime, distinction between different types of organizational learning has been neglected while on the other hand, addressing the issues of customer satisfaction and job satisfaction in the organizations such as insurances are considered as a necessity. Thus, this research tries to review the effect of organizational learning culture on customer satisfaction using job satisfaction's mediating variable. Therefore, given the importance of this research, first we tried to identify, count and classify learning organizations and organizational learning and then determine the different types of learning and factors in this field and in the next step, customer and customer relationship management and their impact on customer satisfaction and job satisfaction were evaluated. The results of the research showed that there is a separate positive relation between each of organizational learning culture, customer satisfaction and job satisfaction variables.
\end{abstract}

Keywords: customer satisfaction, organizational learning culture, job satisfaction, the insurance industry.

\section{SIGORTA SEKTÖRÜNDE İS MEMNUNIYETININ ARACILIK DEĞİSKENİ KULLANARAK ÖRGÜTSEL ÖĞRENME KÜLTÜRÜ VE MÜŞTERİ MEMNUNIYETİ ARASINDAKİ İLIŞKIYYI DEĞERLENDİRMEK}

\section{ÖZ}

Soyut örgütsel öğrenme kültürü, müşteri memnuniyeti ve iş tatmini konusu ile akademik alanda yürütülen faaliyetlerin sayısı örgütsel öğrenme farklı türleri arasında ayrım ihmal edilmiş, İran'da ama bu arada sınırlı değil, diğer yandan da, Bu tür sigortalar gibi kuruluşlarda müşteri memnuniyeti ve iş tatmini konularını ele alan bir zorunluluk olarak kabul edilir. $\mathrm{Bu}$ nedenle, bu araştırma değişkeni aracılık iş tatminini kullanarak müşteri memnuniyetine örgütsel öğrenme kültürü etkisini gözden çalışır. Bu nedenle, bu araştırmanın önemi göz önüne alındığında, ilk önce, tespit saymak ve öğrenen örgütler ve örgütsel öğrenmeyi sınıflandırmak ve daha sonra bu alanda ve bir sonraki adım, müşteri ve müşteri ilişkileri yönetimi ve etkileri farklı öğrenme türleri ve faktörleri belirlenmeye çalışılmıştır müşteri memnuniyeti ve iş tatmini üzerinde değerlendirilmiştir. Araştırma sonuçları örgütsel öğrenme kültürü, müşteri memnuniyeti ve iş doyumu değişkenlerinin her biri arasında ayrı bir pozitif bir ilişki olduğunu göstermiştir.

Anahtar Kelimeler: müşteri memnuniyeti, örgütsel öğrenme kültürü, iş doyumu, sigorta sektörü. 


\section{INTRODUCTION}

Organizations have been created to meet the needs of the environment and customers are one of the most important environmental factors. The organizations will be equally successful to the level of meeting, maintaining or increasing customers' satisfaction. That is why leading and sublime organizations are always looking to ensure customer satisfaction. In today's competitive world, maintaining the existing resources and attracting new resources do not seem so easy. Only firms or organizations that are able to improve their competitive power by increasing the level of quality of products and services according to customers' requirements are successful in the field. Insurance system which is an important component of the economy of any country in a market economy and has a very heavy responsibility, is no exception.

The number of activities undertaken in Iran in the academic field on the topic of organizational learning culture, customer satisfaction and job satisfaction have not been limited. But in the meantime, the thing that has been neglected is distinction between different types of organizational learning while on the other hand, addressing the issues of customer satisfaction and job satisfaction in service organizations including insurance is a necessity.

Organizational learning culture promotes and protects continuous learning and uses it for organizational improvement and progress and supports achieving distribution information and sharing of learning (Pordehkordi, 2011). The importance of job satisfaction stems from the fact that most people spend almost half of their waking hours at work. It is often said that "happy employee is an effective employee" and a happy employee should be with his/her job. The results of this research show that employees with higher job satisfaction are in a better physical and intellectual disabilities conditions. Also experts believe that if lack of enough attention to the real needs of employees will lead to reduced productivity in organization. Interest and positive attitude to the job lead to increased effort and work effort and will ultimately lead reduced costs. Thus, a lot of intellectuals from sociologists and psychologists have focused on job satisfaction in their augments and each have addressed this issue form specific aspects. Because human resource are considered as a source of life and a strategic source for organizations in today's world. This increasing attention has made human resources to be considered as the first customers of organizations who can help in achieving organizational goals (Abtahi, 2008).

\section{RESEARCH TOPIC}

Previous marketing studies have pointed out that the main factor in the success of companies and creating competitive advantage and increasing perceived value, perceived quality and customer satisfaction. Furthermore, complex nature of the services on the one hand and increasing the share of services in the industry on the other hand, have increased the need to upgrade the quality of services in organizations which are seeking to improve financial performance and attract customers in a very competitive environment. The entry of private insurances has created high competition in the insurance industry and has changed the expectations and demands of customers with respect to changing lifestyles, and service provided for them. Thus, it can be concluded that the quality of services will have a positive impact on customer satisfaction and loyalty. Quality of service in the insurance industry has a close relation with customer satisfaction and improving service quality will likely increases customer satisfaction which leads to behavioral outcomes such as commitment, desire to remain, bidirectional link between the service provider and the customer, the customer's tolerance to difficulty in providing services and positive publicity about insurance. Information of the organization's mental picture among customers and factors affecting it will provide a context for adopting appropriate strategies and improving performance.

Customer satisfaction results from the characteristics of supplied product or service. The results of studies on the causes of failure in unsuccessful organizations show that 66 percent of them do not believe in customer satisfaction as a priority. Fully satisfied customers repurchase six times more than satisfied customers over a period of one to two years in customer-oriented organizations (Shahidi, 2010).

Submit Date: 10.02.2016, Acceptance Date: 25.03.2016, DOI NO: 10.7456/1060ASE/029 
The concept of organizational learning culture as a set of norms and values is: obtaining information, interpretation of information and behavioral and cognitive changes (Baharestan et al, 2012). On the other hand work is a man's second home and It is clear that the work environment should also meet the minimum needs of mental health of people like home. Therefore, it is necessary for decision makers to identify factors affecting employees' satisfaction in order of preference and seek to keep employee satisfaction at extremely high levels According to the requirements of that organization and its nature and objectives but only one bad communication of the manager quite tangibly effects of these suitable conditions (Shokri zadeh, 2004).

\section{IMPORTANCE OF THE ISSUE}

Customer retention is critical for success in business in a competitive market and since the retention of current customers is easier and less costly than attracting new customers, organizations that are able to meet their consumer's expectations will be eliminated from the competition on their own.

Nowadays, advances in technology have increased consumer expectations to receive appropriate and timely services and customers are no longer willing to accept any kind of commodity as before. Managers and organization leaders have also found out that they should consider learning as a valuable matter to create a better future for the organization (Huang et al., 2006) because the benefits of the job satisfaction of employees will be for all members of society and citizens. Employees who are satisfied with their jobs take their steps in the direction of citizens' satisfaction. These people have a more positive attitude to life and more form a more mentally healthy society (Robbins, 2011).

\section{THEORETICAL FOUNDATIONS}

\section{LEARNING ORGANIZATION}

Learning Organization is an organization which uses all thinking, knowledge and experience powers of the organization for its development in order to create changes and manages it and makes regular learning possible in order to establish learning and spreading it in the organization and creating a value for learning by having systems and processes such as encouraging people at all levels.

\section{ORGANIZATIONAL LEARNING}

Organizational Learning is processes, mechanisms and methods to realize a learning within the organization to develop learning organization and organizational learning which are: enablers, culture and the environment. Enablers are factors which help the organization to become a learning organization by adopting conscious policies, using Information Technology and encouraging learning in all processes by the behavior of constructive culture managers. Culture and the environment of learning will lead to creation of a learning organization when there are enough markers of culture which include:

The biggest obstacle to organizational learning which is the creation of an empire and use of information as power due to pride and prejudice when learning organizations create different organizational environments to allocating time and money or by sharing information and experience with the aim of investments but the values and beliefs that are entered into conversations and working life of people express vital items for the organization in language, speech, and behavior of individuals in higher levels. Enabler factors will be ineffective even if all of them are provided in case of not having necessary environment for the growth of learning organization.

\section{LEARNING}

Learning is considered in three dimensions:

Levels of learning; different types of learning, learning skills

\section{LEVELS OF LEARNING}

Learning is considered in three levels of individual learning, team learning and organizational learning.

Submit Date: 10.02.2016, Acceptance Date: 25.03.2016, DOI NO: 10.7456/1060ASE/029 
Individual learning: Individuals are forming units of teams and organizations and the commitment of each individual to learn as well as his/her ability to learn are vital for organizations.

Team learning: means that teams think, create and learn as a single unit. This type of learning is based on a one rule and fundamental principle and it has a shared vision but in the meantime personal capabilities are essential elements because capable teams are formed by capable individuals.

Organizational learning: which is obtained through sharing of insight, knowledge, experience and mental models by organization's members. Organizational learning based on knowledge and experience which exists in the memory of organization and is based on mechanisms such as policies, strategies and models of saving knowledge.

Different types of learning:

Learning can have different types but none are completely independent of each other. Each individual, team or organization can be simultaneously use some or all of these methods.

Adaptive learning: at this stage, the individual, team or organization learn from the experience and its reflection.

Prospective learning: it takes place when the organization learns from the future which means defining the best future opportunities and finding ways to achieve it.

Action learning: a method for accelerating the learning and effective in dealing with the problem and effective response to changes which involves the teams as a process.

Learning skills: effective learning requires several skills which means that these skills improve capacity and potentiality of an individual learn more efficiently and better. The most important of these skills are: Systemic thinking: which is a method for interaction between the components that make up the overall behavior and not a connected chain of components.

Mental models: models which include beliefs, assumptions and values which affect our understanding of the world and method of our actions.

Individual domination (capabilities): Means a system in which an individual:

- $\quad$ continuously improves and develops his/her skills

- $\quad$ continuously makes his/her perspective and views brighter and deeper

- $\quad$ expands his/her patience and tolerance

- $\quad$ interprets his/her experiences and learns from them

- fairly and impartially discovers the truth

- $\quad$ has a deep and insightful look into different objects

Self-learning: All members of the organization must learn the method of continuous conscious and with enthusiasm learning and support it and encourage associates and subordinates which requires a commitment to self-learning.

Conversation: which is the best and most qualitative form of innovative and two-way communication and contains the most searched thoughts and ideas as well as the highest explanations, expressions and thoughts. Conversation is the tool and method of team learning. 
Learning is not just to learn but also for success and development of the organization. Lack of learning will lead to suffering from the high costs of duplication and inefficiency and waste of resources or lack of knowledge and skills and the loss of confidence of Individuals and reduced income due to the lack of innovation but profits of the organization will increase and Individuals will be considered as capitals of organized instead of labors when learning and continuous commitment to it take place.

The definition of customer:

Customer is who pays in exchange for services and commodity that receives. There is another definition that says customer is an individual or a group who you exchanged value with. According to this definition even suppliers are considered as customer while according to the first definition, buyer is the customer of the supplier.

The definition of Customer Relationship Management (CRM) (Conway):

There was no information balance between companies and customers (Information asymmetric) and customers accepted vendor's information but it is not the case in today's world. New technologies are affecting today's business conditions. This information balance is not only obtained for the customer in case of the intended company, but the customer also has the ability have the information of similar companies which will meet his/her needs and do not forget that the word in moving from being Productbased toward being Service-Based and technology has caused the point of communicating with customer to be further and further away.

There are two notes about making customers loyal:

Note 1: A customer with a bad experience can remove 8 customers of the organization.

Note 2: there is no need to pay for marketing and ... to sell something to a loyal customer.

Each customer has certainly seen something in provided service or goods which makes him/her come to the seller. Here, any kind of encounter between the seller and the customer is considered as an experience for the customer. If this experience is good, it will make the customer come back, otherwise, the customer will not come back again. This is a reality that the seller is the one who is eliminated if the customers spends his/her capital elsewhere.

CRM Feature is appropriate for valuing customers who are valuable for the system and it is for creation of availability for customers and employees to help expedite decision making, analyze and estimate the services.

\section{THE CONCEPT OF CUSTOMER SATISFACTION}

Philip Kotler defines satisfaction as follows: Pleasant or unpleasant feelings of an individual which emerge by comparison of the goods in comparison with consumer expectations. In this definition, customer satisfaction is a function of product performance and consumer's expectations. If the product performance is less than the expectations, the customer will be dissatisfied and if the product is as good as the consumer's expectations, the customer will be satisfied and if the product is better than the consumer's expectations, the customer will be extremely satisfied.

Satisfaction evaluation process focuses at least on two intervening factors:
A) Source or standard
B) result

Submit Date: 10.02.2016, Acceptance Date: 25.03.2016, DOI NO: 10.7456/1060ASE/029 
Customer satisfaction can also be considered as a response to expectations and final results after consumption (Tese and Wilton 1988) or an emotional reaction which is caused by purchasing with prechosen standards (Hall Steer, Hartmann and skimmer, 1994). It can also be considered as a psychological sense of inconsistent customer expectations which are caused by his/her initial expectations (Oliver, 1981) which leads to creation, development and maintaining customer satisfaction by adding other available features to other experienced emotions after purchasing (Oliver, 1992) and the judgment that is created during consumption of a product or service (Oliver 1996).

\section{JOB SATISFACTION}

There are different definitions for job satisfaction. This concept has been defined in form of "emotional and attitudinal response" of staff to the job. There is a sense of personal satisfaction about jobs in an organization which is in relation with the type of work, abilities and capabilities, the success rate in job, satisfying reasonable needs, talents' prosperity, career improvement, successful experiences and organizational environment (Asadi, 2010).

It can be said in simple terms that job satisfaction can be "The difference between the amount and intensity of individual needs and fulfillment rate of those needs in a job" Which is a direct function of the degree to which the environment is consistent with the structure of the person's needs. Also "job satisfaction is a levels at which people love their jobs" in way that some people enjoy it and others hate it. The basic issue for managers of organizations is that how it is possible to act in way that individuals have personal satisfaction about their work and effort in the organization and acquire rewards at the same time with mobilizing their activities in line with organizational goals (Kamalvand, 2008).

There is no doubt that job satisfaction is very important. Managers have at least three reasons to care about job satisfaction and organizational members which are:

1. Dissatisfied people leave the organization and resign more.

2. Satisfied employees have better health and live longer.

3. Job satisfaction is a phenomenon that goes beyond organization boundaries and its effects and its effects are visible in the private life of the individual and outside of the organization.

\section{THE EFFECTS AND IMPORTANCE OF JOB SATISFACTION}

The importance of job satisfaction is debatable in this respect that satisfied individuals have less absences and leave the organization less. Also job satisfaction has a strong and negative relation with decisions made by an individual about leaving the organization as its negative relation with employee absenteeism.

Among other importance of job satisfaction are its effects on the entire community. When employees and members enjoy their work, their private life (outside the organization) will improve. Considering the foregoing, it can be concluded that reviewing factors affecting job satisfaction is important and recognition of these factors is necessary in order to achieve organizational goals.

Job satisfaction is a phenomenon that goes beyond organizational borders and affects the private lives of individuals outside the organization (Rezaie, 2000). Undoubtedly, the company and its directors should have responsibility and sensitivity about employee satisfaction or dissatisfaction. A number of employees may be dissatisfied about a certain work and consider their job as a temporary work but be satisfied with their organization in general. But when discontent takes the whole organization, probably a larger number of employees will think about resignation, absence or leaving the organization. Knowledge of staff attitudes can help the management in making decisions.

\section{DIFFERENT TYPES OF JOB SATISFACTION}

Job satisfaction has two types from the perspective of Ginsberg and his colleagues: 
Exterior satisfaction: which is always changing and evolving and is in relation with conditions of employment and the workplace. The Remuneration conditions, type of work and the workplace, relationships between employees and employers are among exterior factors.

Internal satisfaction: the first is the pleasure of progress or do some social responsibilities and the appearance of individual human abilities and tastes and the second is the pleasure feeling of a human from employment and activities.

\section{THE DIFFERENCE IN JOB SATISFACTION AND MOTIVATION}

There is a close relation between motivation and job satisfaction, because it is assumed that a high level of motivation leads to psychological consequences including job satisfaction and organizational commitment. It was determined in a research conducted on the employees of the Ministry of Culture and Education that there is a direct relation between motivation and job satisfaction.

According to "Lawler", despite a very close relation between these two concepts, there are also differences between them. In his view, motivation is influenced by forward-looking perceptions. Perceptions which are dealing more with the relation between performance and reward. While satisfaction is in relation with people's feelings about received rewards. Thus, satisfaction is the outcome of past events and motivation is the result of future expectations.

In the other words, Motivation is endeavors to satisfy a desire or goal while satisfaction is a feeling and attitude which is understood after satisfying a desire. Motivation is a psychological state that can motivate people to do something or a desire to do a work. While, satisfaction takes place due to experienced or perceived result.

\section{RESEARCH BACKGROUND}

Azariyun, Seyyed Amraleh (2013) carried out a research entitled "the relation between spiritual leadership and organizational learning and Job satisfaction among teachers in the education department of Dehdasht city" in 2012-13 academic year with the sample size of 180 and the results after data analysis showed that the dimensions of knowledge acquisition and application of knowledge had no significant relation with job satisfaction but knowledge sharing has a positive and significant relation with job satisfaction.

Asadi Nezhad, Maryam (2011) carried out a research entitled "evaluating the effect of organizational learning culture on employee creativity in Gilan Regional Electric Company" in June 2011 and the obtained results show that organizational learning culture has had effect on employee creativity in several aspects such as continuous learning, teamwork and integrated system.

Baharestan, Omid, Hossein Rezai Dolat Abadi and Mohammad Mohammedi Sadr (2012) carried out a research entitled "Analysis of relationship between organizational learning culture, innovative culture and innovation in the food industry of Kerman (Cases of the Study: Zamzam, oil and Pegah companies of Kerman)" in which questionnaire was used for data collection. The results obtained from the analysis of route community and a sample of 629 and 238 people which were selected randomly - stratified showed that Organizations to strengthen organizational learning culture must learn how to interpret the information and emphasis on it and try to accurately complete the processes related to each variable by increasing the impact of learning on innovation capability.

Habibpour Dehkordi, Maryam (2011) carried out a research entitled "evaluating the effect of organizational learning culture on job satisfaction and organizational commitment, Case Study of Gas Company of Chaharmahal and Bakhtiari Province" The study population 152 people and in 2010 using a random sampling method and expressed the importance of having a strong organizational learning culture

Submit Date: 10.02.2016, Acceptance Date: 25.03.2016, DOI NO: 10.7456/1060ASE/029 
in the organization which improves the performance of employees and organizations as well as their commitment to the organization and increases job satisfaction.

Also Zareian, Maryam (2013) carried out a study entitled "evaluation of relation between organizational learning culture and organizational capacity; does transformational leadership have an important moderating effect?" for study population consisted of 450 employees, managers and professors of the management Faculty of Shahid Beheshti and Tehran Universities. The findings of this research show that transformational leadership moderates the relationship between organizational learning culture and organizational capacity.

Elahavi Nazar, Elahe (2012) carried out a study entitled "evaluation of the effect of organizational learning culture on the culture of innovation and creativity in Saderat Bank (a case Study on branches and supervision departments of north Tehran)" in which the results show that organizational learning culture has a direct, positive and strong effect on innovation.

Babagoli Ahangarkola, Hassan (2012) carried out a study entitled "the relation between organizational learning, job satisfaction and organizational commitment of Physical education teachers in Mazandaran" on 300 subjects who were selected randomly and in clusters. Then obtained results show that there is a direct relation between job satisfaction and organizational learning.

Hiss and Hill, (2001) showed that employees motivation and organizational learning are positively related to perceived service quality. They concluded that having motivated staff and organizational learning ability are essential to achieve higher service quality. Mac Kelloway and Weiss, (2002), also showed that motivating employees to improve performance through learning is necessary for the organization in order to develop individual performance. In this regard, the research of Lee Paine et al (2004) showed that learning motivation is positively associated with learning function.

Also, the research of Dizhi (2005) showed that there is a significant relation organizational learning culture and learning motivation and internal service quality and organizational learning culture determines $5 \%$ of the Internal service quality variance. The research of Eigen and his colleagues showed that there is a relation between organizational learning culture and non-financial variables such as incentives to move. Engoni et al (2006) reviewed "the effect of transformational and transactional leadership on job satisfaction, organizational commitment and organizational citizenship behaviors of elementary teachers in Tanzania" in their study. Regression analysis showed that dimensions of transformational leadership have a strong impact on job satisfaction, organizational commitment and organizational citizenship behaviors of teachers. It was also shown that although transactional leadership is related to the mentioned variables but it is a weaker predictor for these variables compared to transformational leadership.

The results of Mehmet's study (2007) entitled "the effect of Leadership styles on organizational health" showed that transformational leadership has a profound effect on job satisfaction of teachers. While transformational leadership of managers directly and indirectly through job satisfaction of teachers affects organizational health.

Garcia and Morales (2008) evaluated the effect of Transformational Leadership on Organizational Innovation and Performance which depends on level of organizational learning in industrial companies. The findings show that there is a positive relation between transformational leadership and organizational innovation, between transformational leadership and organizational performance and between organizational innovation and organizational performance.

Gamos logo and Ile Seo, (2009), stated that Transformational leadership affects customer satisfaction and they found out that these two factors have a huge impact on each other.

Submit Date: 10.02.2016, Acceptance Date: 25.03.2016, DOI NO: 10.7456/1060ASE/029 
The aim of this study was to study the role of communication, organizational learning processes in customer satisfaction. Organizational learning culture has a major impact on improving performance and organizational innovation and motivates employees, improves the quality of services and motivates learning in its various dimensions. In this study, job satisfaction is considered as a mediating variable.

Finally, the researcher has tried to provide a definition for organizational learning culture, but there have not been similar opinions in relation to its definition. But in general, it can be defined as the method of classification and analysis of data to maintain and increase the level of commitment and organizational capacity along with job satisfaction and organization's customers' satisfaction.

\section{RESEARCH OBJECTIVES}

Given the importance and necessity of organizational learning culture, Job satisfaction and customer satisfaction, the researcher tried to carry out a research with main objective of evaluating the relation between organizational learning culture and customer satisfaction in the insurance industry and in the meantime in addition to evaluation of the relationship between organizational learning culture and job satisfaction as well as customer satisfaction through a mediator variable of job satisfaction, be able to evaluate the relation between job satisfaction and customer satisfaction as the study's secondary objectives.

\section{RESEARCH QUESTIONS}

Main and sub questions related to this study are as follows:

The main question

- $\quad$ Is there a significant relation between organizational learning culture and customer satisfaction in the insurance industry?

Sub questions

- Is there a significant relation between organizational learning culture and job satisfaction in the insurance industry?

- Is there a significant relation between organizational learning culture and customer satisfaction through the mediating variable of job satisfaction in the insurance industry?

- Is there a significant relation between job satisfaction and customer satisfaction in the insurance industry?

Conceptual model of the research:

The objective of the present study is examination of the relation between organizational learning culture and customer satisfaction through the mediating variable of job satisfaction in the insurance industry. Thus, considering the introduced variables and research hypotheses, the research model is as follows:

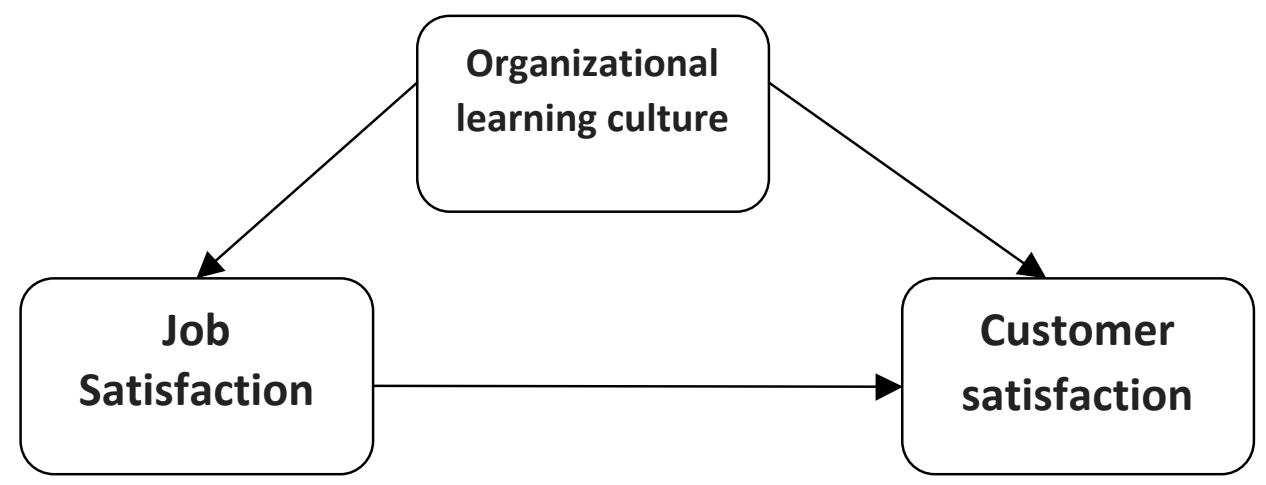

Submit Date: 10.02.2016, Acceptance Date: 25.03.2016, DOI NO: 10.7456/1060ASE/029 


\section{RESEARCH HYPOTHESES}

1. There is a significant relation between organizational learning culture and customer satisfaction in the insurance industry

2. There is a significant relation between organizational learning culture and job satisfaction in the insurance industry

3. There is a significant relation between organizational learning culture and customer satisfaction through the mediating variable of job satisfaction in the insurance industry

4. There is a significant relation between job satisfaction and customer satisfaction in the insurance industry

\section{RESEARCH METHOD}

The present study is based on the nature method of a descriptive - survey study. Books were used to clarify the theoretical issues and gather information and articles and researches of other researchers were used to collect data in the field of research background and literature. Questionnaire with a range of five option Likert ranking has been used to collect data in order to survey customers, employees and hypothesis testing. The questionnaire consisted of two parts; the first part has questions about gender, age, type of employment, work experience, education, and organizational position and the second part contains a series of closed questions and has collected the opinions of experts and insurance policyholders of Iran insurance Company during provision and use of insurance products and services.

The study population consisted of policyholders and experts of Iran Insurance Company with a determined number and the Cochran formula was used to determine the minimum required sample size:

$$
n=\frac{N z^{2} a / 2 P(1-P)}{(N-1) d^{2}+z^{2} a / 2 P(1-P)}
$$

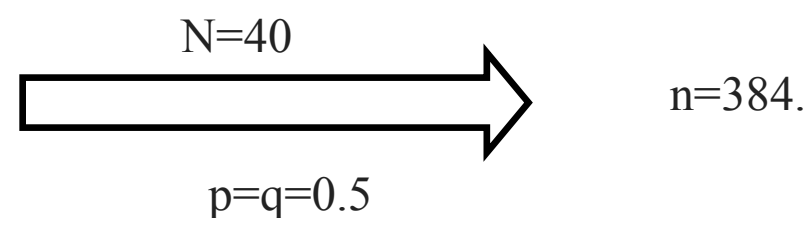

The Cochran formula for unlimited population is also used to determine the minimum required sample size of policyholders:

$$
n=\frac{z^{2} p q}{d^{2}}
$$

If the value of $\mathrm{p}$ is not available, it can be considered to be 0.5 (Azar and Momeni, 2008) which was also considered to be 0.5 in the present study and the required sample size is 384.16 individuals by placement of parameters in the mentioned formula and a total of 400 questionnaires were distributed among the population among which 385 completed questionnaires were the basis of the analysis.

The minimum required sample size of Iran Insurance Company's experts were 196 individuals and the number of required policyholders were 385 individuals which were the basis of the analysis.

\section{RELIABILITY OF RESEARCH}

A reliable tool is the one which has identical measurement and reproducibility features. One of the widely used tools for measuring reliability is measuring reliability with Cronbach's alpha which is easily calculated using SPSS software and its formula is as follows: 
$r_{a}=\frac{j}{j-1}\left(1-\frac{\sum s_{i}^{2}}{s^{2}}\right)$

In which:

$\mathrm{j}=$ the number of test or questionnaire subset

$S_{i}^{2}=$ the variance of subset

$S^{2}=$ The total variance

Table 1: Reliability Statistics

\begin{tabular}{|c|c}
\hline N of Items & Cronbach's Alpha \\
\hline 20 & 0.815 \\
\hline
\end{tabular}

VALIDATION OF THE RESEARCH MODEL

The correlation coefficient is a statistic to measure the strength of the linear relation between two variables and has been defined in a way that it can change in range of 1 and -1 . Values close to 1 and -1 indicate a strong relation between the two variables. While values close to zero reduce the relation between two variables while two variables have no relation with each other at zero.

Thus, the following correlation coefficients are used in order to analyze information after collecting raw data and extracting them:

1. Kendall's correlation coefficient which is a non-parametric test and is used to determine the amount of relation between nominal and ordinal variables as well as the amount of coordination among opinions for analysis.

2. Pearson correlation coefficient to determine the frequency, type and direction of the relation between two interval or relative variables (Quantitative) or an interval variable and a relative variable.

3. The Spearman correlation coefficient which represents the nonparametric Pearson's correlation coefficient and uses the ranks of variable instead of using their values and one of the advantage of Spearman correlation coefficient compared to Pearson correlation coefficients is that if one or more of data are very large compared to other numbers, other data are not overshadowed because only their rankings are calculated.

4. Also regression analysis was used to examine and test hypotheses

\section{RESEARCH FINDINGS}

First, we mention each hypothesis at this stage. Then, we will use zero and one hypothesis testing and 0.01 test level in order to test it. The Correlational relation between any two variables (Based on the conceptual model) is tested using spss software. For this purpose, regression analysis is used to find the equation and its result after rejecting the hypothesis of the lack of relation and approving the hypothesis of the existence of relation. Also, the variables are named as follows at all stages of the research:

X1: Organizational learning culture

X2: Job Satisfaction

X3: Customer satisfaction

Hypothesis 1:

There is a significant relation between organizational learning culture and customer satisfaction in the insurance industry. To evaluate this, we will first evaluate the relation between these two variables:

A) Creating H0 hypothesis:

Submit Date: 10.02.2016, Acceptance Date: 25.03.2016, DOI NO: 10.7456/1060ASE/029 
There is no significant relation between organizational learning culture and customer satisfaction in the insurance industry.

$\mathrm{H} 0: \mathrm{P}=0$

B) Creating H1 hypothesis:

There is a significant relation between organizational learning culture and customer satisfaction in the insurance industry.

$\mathrm{H} 1: \mathrm{P} \neq 0$

Table 2: the Pearson values of $\mathrm{x} 1$ and $\mathrm{x} 3$ variables

\begin{tabular}{|c|l|c|c|}
\hline \multicolumn{2}{|c|}{ Correlations } & $\mathbf{x 1}$ & $\mathbf{x 3}$ \\
\hline \hline \multirow{3}{*}{$\mathbf{x 1}$} & Pearson Correlation & 1 & $.424(* *)$ \\
\cline { 2 - 5 } & Sig. (2-tailed) & & .000 \\
\cline { 2 - 4 } & $\mathbf{N}$ & 360 & 360 \\
\hline \hline \multirow{3}{*}{$\mathbf{x 3}$} & Pearson Correlation & $.424(* *)$ & 1 \\
\cline { 2 - 4 } & Sig. (2-tailed) & .000 & \\
\cline { 2 - 4 } & $\mathbf{N}$ & 360 & 360 \\
\hline \multirow{2}{*}{$* *$ Correlation is significant at the 0.01 level (2-tailed). } \\
\hline
\end{tabular}

As is clear from the results of Pearson the hypothesis of no relation between these two variables is rejected and their correlation value is 0.424 and Kendall and Spearman correlations are respectively 0.487 and 0.633 which all indicate the relation between these variables.

Table 3: the Kendall and Spearman values of $\mathrm{x} 1$ and $\mathrm{x} 3$ variables

\begin{tabular}{|c|c|c|c|c|}
\hline \multicolumn{3}{|c|}{ Correlations } & $\mathbf{x 1}$ & $\mathbf{x} 3$ \\
\hline \multirow{6}{*}{$\begin{array}{c}\text { Kendall's } \\
\text { tau_b }\end{array}$} & \multirow{3}{*}{$\mathbf{x 1}$} & Correlation Coefficient & 1.000 & $.487(* *)$ \\
\hline & & Sig. (2-tailed) & . & .000 \\
\hline & & $\mathbf{N}$ & 360 & 360 \\
\hline & \multirow{3}{*}{$\mathbf{x} 3$} & Correlation Coefficient & $.487(* *)$ & 1.000 \\
\hline & & Sig. (2-tailed) & .000 & . \\
\hline & & $\mathbf{N}$ & 360 & 360 \\
\hline \multirow{6}{*}{$\begin{array}{l}\text { Spearman's } \\
\text { rho }\end{array}$} & \multirow{3}{*}{$x 1$} & Correlation Coefficient & 1.000 & $.633(* *)$ \\
\hline & & Sig. (2-tailed) & . & .000 \\
\hline & & $\mathbf{N}$ & 360 & 360 \\
\hline & \multirow{3}{*}{$\mathbf{x} 3$} & Correlation Coefficient & $.633(* *)$ & 1.000 \\
\hline & & Sig. (2-tailed) & .000 & . \\
\hline & & $\mathbf{N}$ & 360 & 360 \\
\hline
\end{tabular}


** Correlation is significant at the 0.01 level (2-tailed).

Regression analysis indicates that the relation between organizational learning culture and customer satisfaction is with effectiveness value of 0.398 which is also significant because it has t-student statistic value higher than 2. Regression model is also significant because $\mathrm{F}$ statistic is equal to 29.599.

Table 4: The Regression results

\begin{tabular}{|c|c|c|c|c|c|c|}
\hline \multicolumn{7}{|c|}{ Coefficients(a) } \\
\hline \multirow{2}{*}{ Model } & & \multicolumn{2}{|c|}{$\begin{array}{l}\text { Unstandardized } \\
\text { Coefficients }\end{array}$} & \multirow{2}{*}{$\begin{array}{c}\begin{array}{c}\text { Standardized } \\
\text { Coefficients }\end{array} \\
\text { Beta }\end{array}$} & \multirow[t]{2}{*}{$\mathbf{t}$} & \multirow[t]{2}{*}{ Sig. } \\
\hline & & B & Std. Error & & & \\
\hline \multirow{2}{*}{1} & (Constant) & 17.193 & 1.880 & .000 & 9.143 & .000 \\
\hline & $\mathbf{x 1}$ & .398 & .073 & .276 & 5.440 & .000 \\
\hline
\end{tabular}

Hypothesis 2:

There is a significant relation between organizational learning culture and job satisfaction in the insurance industry. To evaluate this, we will first evaluate the relation between these two variables:

A) Creating $\mathrm{HO}$ hypothesis:

There is no significant relation between organizational learning culture and job satisfaction in the insurance industry.

$\mathrm{H} 0: \mathrm{P}=0$

B) Creating H1 hypothesis:

There is a significant relation between organizational learning culture and job satisfaction in the insurance industry.

$\mathrm{H} 1: \mathrm{P} \neq 0$

Table 5: the Pearson values of $\mathrm{x} 1$ and $\mathrm{x} 2$ variables

\begin{tabular}{|c|l|c|c|}
\hline \hline \multicolumn{2}{|c|}{ Correlations } & $\mathbf{x 1}$ & $\mathbf{x 2}$ \\
\hline \hline \multirow{3}{*}{$\mathbf{x} 1$} & Pearson Correlation & 1 & $.276\left(^{* *}\right)$ \\
\cline { 2 - 4 } & Sig. (2-tailed) & & .000 \\
\cline { 2 - 4 } & $\mathbf{N}$ & 360 & 360 \\
\hline \hline \multirow{3}{*}{$\mathbf{x 2}$} & Pearson Correlation & $.276\left(^{* *}\right)$ & 1 \\
\cline { 2 - 4 } & Sig. (2-tailed) & .000 & \\
\cline { 2 - 4 } & $\mathbf{N}$ & 360 & 360 \\
\hline \hline \multirow{2}{*}{$* *$ Correlation is significant at the 0.01 level (2-tailed). } \\
\hline
\end{tabular}


As is clear from the results of Pearson the hypothesis of no relation between these two variables is rejected and their correlation value is 0.276 and Kendall and Spearman correlations are respectively 0.578 and 0.734 which all indicate the relation between these variables.

Table 6: the Kendall and Spearman values of $\mathrm{x} 1$ and $\mathrm{x} 2$ variables

\begin{tabular}{|c|c|c|c|c|}
\hline \multicolumn{3}{|c|}{ Correlations } & $\mathbf{x 1}$ & $\mathbf{x} 2$ \\
\hline \multirow{6}{*}{$\begin{array}{c}\text { Kendall's } \\
\text { tau_b }\end{array}$} & \multirow{3}{*}{$\mathbf{x} 1$} & $\begin{array}{l}\text { Correlation } \\
\text { Coefficient }\end{array}$ & 1.000 & $.578(* *)$ \\
\hline & & Sig. (2-tailed) & . & .000 \\
\hline & & $\mathbf{N}$ & 360 & 360 \\
\hline & \multirow{3}{*}{$\mathrm{x} 2$} & $\begin{array}{l}\text { Correlation } \\
\text { Coefficient }\end{array}$ & $.578(* *)$ & 1.000 \\
\hline & & Sig. (2-tailed) & .000 & . \\
\hline & & $\mathbf{N}$ & 360 & 360 \\
\hline \multirow{6}{*}{$\begin{array}{l}\text { Spearman's } \\
\text { rho }\end{array}$} & \multirow{3}{*}{$\mathbf{x} 1$} & $\begin{array}{l}\text { Correlation } \\
\text { Coefficient }\end{array}$ & 1.000 & $.734(* *)$ \\
\hline & & Sig. (2-tailed) & . & .000 \\
\hline & & $\mathbf{N}$ & 360 & 360 \\
\hline & \multirow{3}{*}{$\mathbf{x} 2$} & $\begin{array}{l}\text { Correlation } \\
\text { Coefficient }\end{array}$ & $.734(* *)$ & 1.000 \\
\hline & & Sig. (2-tailed) & .000 & . \\
\hline & & $\mathbf{N}$ & 360 & 360 \\
\hline
\end{tabular}

Regression analysis indicates the significance of Regression model because F statistic is equal to 78.665 and organizational learning culture effectiveness value is 0.233 which is also significant because it has tstudent statistic value equal to 8.869 .

Table 7: the Regression Results

\begin{tabular}{|c|c|c|c|c|c|c|}
\hline \multicolumn{7}{|c|}{ Coefficients(a) } \\
\hline \multirow{2}{*}{ Model } & & \multicolumn{2}{|c|}{$\begin{array}{c}\text { Unstandardized } \\
\text { Coefficients }\end{array}$} & \multirow{2}{*}{$\begin{array}{c}\begin{array}{c}\text { Standardized } \\
\text { Coefficients }\end{array} \\
\text { Beta }\end{array}$} & \multirow{2}{*}{$\mathbf{t}$} & \multirow{2}{*}{ Sig. } \\
\hline & & B & Std. Error & & & \\
\hline \multirow{2}{*}{1} & (Constant) & 11.077 & .648 & .000 & 17.099 & .000 \\
\hline & $\mathrm{x} 1$ & .223 & .025 & .424 & 8.869 & .000 \\
\hline
\end{tabular}

Hypothesis 3: 
There is a significant relation between organizational learning culture and customer satisfaction through the mediating variable of job satisfaction in the insurance industry. To evaluate this, we will first evaluate the relation between these two variables:

A) Creating H0 hypothesis:

There is no significant relation between organizational learning culture and customer satisfaction through the mediating variable of job satisfaction in the insurance industry.

$\mathrm{H} 0: \mathrm{P}=0$

B) Creating H1 hypothesis:

There is a significant relation between organizational learning culture and customer satisfaction through the mediating variable of job satisfaction in the insurance industry.

$\mathrm{H} 1: \mathrm{P} \neq 0$

Table 8: the Pearson values of $\mathrm{x} 1$ and $\mathrm{x} 2$ and $\mathrm{x} 3$ variables

\begin{tabular}{|c|c|c|c|c|}
\hline \multicolumn{2}{|c|}{ Correlations } & $\mathbf{x 1}$ & $\mathbf{x} 2$ & $\mathbf{x} 3$ \\
\hline \multirow{3}{*}{$\mathbf{x 1}$} & Pearson Correlation & 1 & $.276(* *)$ & $.424(* *)$ \\
\hline & Sig. (2-tailed) & & .000 & .000 \\
\hline & $\mathbf{N}$ & 360 & 360 & 360 \\
\hline \multirow{3}{*}{$\mathbf{x 2}$} & Pearson Correlation & $.276(* *)$ & 1 & $.544(* *)$ \\
\hline & Sig. (2-tailed) & .000 & & .000 \\
\hline & $\mathbf{N}$ & 360 & 360 & 360 \\
\hline \multirow{3}{*}{$\mathbf{x 3}$} & Pearson Correlation & $.424(* *)$ & $.544(* *)$ & 1 \\
\hline & Sig. (2-tailed) & .000 & .000 & \\
\hline & $\mathbf{N}$ & 360 & 360 & 360 \\
\hline
\end{tabular}

The Pearson statistic shows the values of 0.276 and 0.424 for two $\mathrm{X} 2$ and $\mathrm{x} 3$ variables which is an optimal amount and shows the correlation. Kendall statistics and Spearman statistics respectively showed the values of 0.487 and 0.633 for X3 variable and 0.578 and 0.734 for X2 variable which indicate the correlation between variables.

Table 9: the Kendall and Spearman values of $\mathrm{x} 1$ and $\mathrm{x} 2$ and $\mathrm{x} 3$ variables

\begin{tabular}{|c|c|c|c|c|c|}
\hline \multicolumn{3}{|c|}{ Correlations } & $\mathbf{x 1}$ & $\mathbf{x} 2$ & $\mathbf{x 3}$ \\
\hline \multirow{4}{*}{ Kendall's tau_b } & \multirow{3}{*}{$\mathbf{x 1}$} & \begin{tabular}{|l|} 
Correlation \\
Coefficient
\end{tabular} & 1.000 & $.578(* *)$ & $.487(* *)$ \\
\hline & & Sig. (2-tailed) & . & .000 & .000 \\
\hline & & $\mathbf{N}$ & 360 & 360 & 360 \\
\hline & $\mathbf{x} 2$ & $\begin{array}{l}\text { Correlation } \\
\text { Coefficient }\end{array}$ & $.578(* *)$ & 1.000 & $.655(* *)$ \\
\hline
\end{tabular}




\begin{tabular}{|c|c|c|c|c|c|}
\hline & & |Sig. (2-tailed) & .000 & . & .000 \\
\hline & & $\mid \mathbf{N}$ & 360 & 360 & 360 \\
\hline & \multirow{3}{*}{ |x3 } & \begin{tabular}{||l} 
Correlation \\
Coefficient
\end{tabular} & $.487(* *)$ & $.655(* *)$ & 1.000 \\
\hline & & |Sig. (2-tailed) & .000 & .000 & . \\
\hline & & $\mid \mathbf{N}$ & 360 & 360 & 360 \\
\hline \multirow{9}{*}{ Spearman's rho } & \multirow{3}{*}{$\mathbf{x} 1$} & \begin{tabular}{||l} 
Correlation \\
Coefficient
\end{tabular} & 1.000 & $.734(* *)$ & $.633(* *)$ \\
\hline & & |Sig. (2-tailed) & . & .000 & .000 \\
\hline & & $\mid \mathbf{N}$ & 360 & 360 & 360 \\
\hline & & \begin{tabular}{|l} 
Correlation \\
Coefficient
\end{tabular} & $.734(* *)$ & 1.000 & $.819(* *)$ \\
\hline & $\mid \mathbf{x} 2$ & Sig. (2-tailed) & .000 & . & .000 \\
\hline & & $\mathbf{N}$ & 360 & 360 & 360 \\
\hline & & \begin{tabular}{||l} 
Correlation \\
Coefficient
\end{tabular} & $.633(* *)$ & $.819(* *)$ & 1.000 \\
\hline & ||x3 & Sig. (2-tailed) & .000 & .000 & . \\
\hline & & $\| \mathbf{N}$ & 360 & 360 & 360 \\
\hline
\end{tabular}

In evaluation of the relation between organizational learning culture and customer satisfaction through mediating variable of job satisfaction, "job satisfaction" is as an interface between organizational learning culture (independent variable) and customer satisfaction (dependent variable) and since it cannot be places in a unit model as predictor variables as well as due to being placed in class or ordinal (ranking) sizes, its Regression analysis is impossible.

Hypothesis 4:

There is a significant relation between job satisfaction and customer satisfaction in the insurance industry. To evaluate this, we will first evaluate the relation between these two variables:

A) Creating H0 hypothesis:

There is no significant relation between job satisfaction and customer satisfaction in the insurance industry.

$\mathrm{H} 0: \mathrm{P}=0$

B) Creating H1 hypothesis:

There is a significant relation between job satisfaction and customer satisfaction in the insurance industry. $\mathrm{H} 1: \mathrm{P} \neq 0$ 
Table 10: the Pearson values of $\mathrm{x} 2$ and $\mathrm{x} 3$ variables

\begin{tabular}{|c||l|c|c|}
\hline \hline \multicolumn{2}{|c|}{ Correlations } & $\mathbf{x 2}$ & $\mathbf{x 3}$ \\
\hline \hline \multirow{3}{*}{$\mathbf{x} 2$} & Pearson Correlation & 1 & $.544(* *)$ \\
\cline { 2 - 4 } & Sig. (2-tailed) & & .000 \\
\cline { 2 - 4 } & $\mathbf{N}$ & 360 & 360 \\
\hline \hline \multirow{3}{*}{$\mathbf{x 3}$} & Pearson Correlation & $.544(* *)$ & 1 \\
\cline { 2 - 4 } & Sig. (2-tailed) & .000 & \\
\cline { 2 - 4 } & $\mathbf{N}$ & 360 & 360 \\
\hline \hline \multirow{2}{*}{$* *$ Correlation is significant at the 0.01 level (2-tailed). } & \\
\hline
\end{tabular}

As is clear from the results of Pearson indicates the existence of correlation between two variables with the value of 0.544 and Kendall and Spearman correlations are respectively 0.655 and 0.816 which all indicate the relation between these variables.

Table 11: the Kendall and Spearman values of $x 2$ and $x 3$ variables

\begin{tabular}{|c|c|c|c|c|}
\hline \multicolumn{3}{|c|}{ Correlations } & $\mathbf{x} 2$ & $\mathbf{x} 3$ \\
\hline \multirow{6}{*}{$\begin{array}{c}\text { Kendall's } \\
\text { tau_b }\end{array}$} & \multirow{3}{*}{$\mathbf{x 2}$} & \begin{tabular}{||l} 
Correlation \\
Coefficient
\end{tabular} & 1.000 & $.655(* *)$ \\
\hline & & Sig. (2-tailed) & . & .000 \\
\hline & & $\mathbf{N}$ & 360 & 360 \\
\hline & \multirow{3}{*}{$\mathbf{x} 3$} & \begin{tabular}{||l} 
Correlation \\
Coefficient
\end{tabular} & $.655(* *)$ & 1.000 \\
\hline & & Sig. (2-tailed) & .000 & \\
\hline & & $\mathbf{N}$ & 360 & 360 \\
\hline \multirow{6}{*}{$\begin{array}{l}\text { Spearman's } \\
\text { rho }\end{array}$} & \multirow{3}{*}{$\mathbf{x} 2$} & \begin{tabular}{||l} 
Correlation \\
Coefficient
\end{tabular} & 1.000 & $.819(* *)$ \\
\hline & & Sig. (2-tailed) & . & .000 \\
\hline & & $\mid \mathbf{N}$ & 360 & 360 \\
\hline & \multirow{3}{*}{$\mathbf{x 3}$} & \begin{tabular}{||l} 
Correlation \\
Coefficient
\end{tabular} & $.819(* *)$ & 1.000 \\
\hline & & Sig. (2-tailed) & .000 & \\
\hline & & $\mid \mathbf{N}$ & 360 & 360 \\
\hline
\end{tabular}

The results of the regression analysis indicates the significance of regression model used in the case of these two variables because it has F-statistic equal to 150.367 and Job satisfaction coefficient equal to 
0.199. This value is also significant because it has Student t-test value equal to 12.263 which is an optimal value.

Table 12: the Regression Results

\begin{tabular}{|c|c|c|c|c|c|c|}
\hline \multicolumn{7}{|c|}{ Coefficients(a) } \\
\hline \multirow{2}{*}{ Model } & & \multicolumn{2}{|c|}{$\begin{array}{l}\text { Unstandardized } \\
\text { Coefficients }\end{array}$} & \multirow{2}{*}{$\begin{array}{c}\begin{array}{c}\text { Standardized } \\
\text { Coefficients }\end{array} \\
\text { Beta }\end{array}$} & \multirow[t]{2}{*}{$\mathbf{t}$} & \multirow[t]{2}{*}{ Sig. } \\
\hline & & B & Std. Error & & & \\
\hline \multirow{2}{*}{1} & (Constant) & 11.137 & .482 & .000 & ||23.102 & .000 \\
\hline & $\mathrm{X3}$ & 199 & .016 & .544 & ||12.262 & .000 \\
\hline
\end{tabular}

\section{CONCLUSION}

Agreement on the number of factors and components of customer satisfaction or a model that can measure all factors affecting customer satisfaction are essential requirements for an organization that takes steps on the path to excellence. Organizations that want to always be superior must create sustainable value for the customer based on the principle of Customer Orientation and act beyond his expectations.

The present research seeks to find the relation between organizational learning culture, customer satisfaction and job satisfaction in the insurance industry by providing a model. The findings of the research showed that there is a significant relation between the variables of organizational learning culture and customer satisfaction. The results also showed a significant relation between the variables of organizational learning culture and job satisfaction which can be said that the process of organizational behavior improvement through qualitative and quantitative promotion of organizational learning culture at all levels of the organization will increase customer satisfaction as the main variable and job satisfaction as a mediator. Also, due to the effects of organizational learning culture, we found out that this variable has a greater effect on job satisfaction.

\section{LIMITATIONS}

Some of the imitations in this study are as follows:

1. Lack of enough resources and information

2. Lack familiarity with operational planning principles

3. Using traditional and unscientific methods

4. Lack of cooperation in the process of gathering information

The above mentioned notes and some other minor issues led to spending a lot of time and costs to obtain the approval and trust of studied individuals and organizations.

\section{RECOMMENDATIONS}

The following items are a part of administrative and operational recommendations based on this research:

1. Iran Insurance Company can improve it data collection methods for strengthening and differentiation of their services from competitors using a strategic and dynamic approach. 
2. Periodic evaluation of the level of policyholders' satisfaction about the services they received and staff about conditions of employment and identifying possible strengths and weaknesses to understand the shortcomings and providing suggestions for improving the quality of provided services.

3. Senior Managers should pay special attention to raising the level of job satisfaction through establishment of organizational learning programs and improving human resources' system in the organization according to the needs and expectations of their policyholders.

\section{REFERENCES}

1. Robbins, Stephen. (2011), Organizational Behavior Management (personal conduct) translated the first volume Parsaeian, Ali. Arabs, SM, published by the Institute for Trade Studies and Research of Tehran.

2. Khademi, Zare, H., \& Fakhrzad, M. (2010). Prioritize the factors motivating employees to increase productivity. Management and human resources.

3. Bazargan, Abbas, Sarmad, Zohre; Hejazi, Elahe, (2009), knowledgeable publications in behavioral science research methods.

4. Ranjbarian, Bahram, Rashid Kaboli, Majid, Sanayeie, Ali; Hadadian, AliReza; analysis of the relationship between perceived value and intention to repurchase chain stores in Tehran, Journal of Business Administration, 2012

5. Azar, Adel and Momeni, Mansour, (2008), Statistics and Its Application in Management, Volume II, Tehran, publisher side.

6. Babai, Ayazallah, (2004), "Integration of knowledge management and organizational learning", devise, No. 146.

7. Rahimnia, F., Harandi, P., \& Fatemi, Z. (2012). The quality of the relationship with the customer perceived quality and loyalty of study: five-star hotels Mashhad metropolitan city. Research General Manager.

8. Kivi and Campenhood, (2009), research methods in the social sciences, translator Abdul Nick Gohar sulphate emissions.

9. Hosseini HashemiZadeh, Davood, to investigate the factors affecting customer satisfaction Bank of Industry and Mine, Journal of Business Administration, 2009

10. Rafiepour, Faramarz, (1999), specific research techniques in Social Sciences, Tehran, joint publication of the fourth edition.

11. Ghafari, Farhad, Jafari, Pejman, Amir Madhi, Ashkan, study the relationship between quality of service and customer satisfaction in the banking industry, Journal of Management Sciences, 2012

12. Howat, G., \& Assaker, G. (2013). The hierarchical effects of perceived quality on perceived value, satisfaction, and loyalty: Empirical results from public, outdoor aquatic centres in Australia. Sport Management Review.

13. Salomann Harald, Dous Malt, Luztz Kolbe,Walter Brenner,(2005(,Rejuvenating Customer Management: How to Make Knowledge For, From and About Customers Work, European Management Journal Vol. 23, No. 4, pp. $392-403$.

14. Malhoyra, "Effective Customer Relationship Managment by Customer Knowledge Managment," Handbook of Customer Relationship Managment ", (2001).

15. Jorge Vera, Andrea Trujillo, Service quality dimensions and superior customer perceived value in retail banks: An empirical study on Mexican consumers, Journal of Retailing and Consumer Services, 2013.

16. Beerli, A., Martin, J.D, \& Quintana, A. (2004). A Model of Customer Loyalty in the Retail Banking Market. European Journal of Marketing. Vol. 38, No. 1/2, pp. 253 - 275.

17. Silvia Martelo, Carmen Barroso, Gabriel Cepeda, The use of organizational capabilities to increase customer value, Journal of Business Research, 2013. 